\section{Jesuit Education 21: Conference on the Future of Jesuit Higher Education}

\section{Kathleen A. Mahoney}

Kathleen A. Mahoney is assistant professor of higher education at Boston College. Address: Campion Hall, Boston College, Chestnut Hill, MA 02467.

$\mathrm{O}$ n June 25, 1999, over 300 people gathered at St. Joseph's University in Philadelphia for "Jesuit Education 21: Conference on the Future of Jesuit Higher Education." Those assembled for the five-day conference represented a spectrum of persons involved in and concerned about Jesuit and Catholic higher education and included representatives from the Vatican, almost all of the 28 Jesuit colleges in the United States, and several Jesuit colleges from other countries. Among them were university presidents, faculty members, independent scholars, administrators, staff members, students, and alumni.

The Conference was organized by Martin Tripole, S.J., associate professor of theology at St. Joseph's University, whose recently published edited volume, Promise Renewed: Fesuit Higher Education for a New Millennium (Loyola Press, 1999), served as a catalyst for the conference. The timing of the conference coincided not only with the advent of the new millennium and the 21 st century, but the 400th anniversary of the publication of the historic Ratio Studiorum, the influential pedagogical guide to Jesuit education. The last gathering of its kind was Assembly '89, held at Georgetown University in Washington, D.C.

After a videotaped greeting from Peter-Hans Kolvenbach, S.J., Superior General of the Society of Jesus, and greetings from the Archbishop of Philadelphia, New York Times religion writer Peter Steinfels delivered the keynote address on "A Mission for Jesuit Education in the 21st Century." He was followed by over 70 national and international speakers and panelists, Jesuit and lay, who brought to bear their convictions and expertise about Jesuit education and sparked lively discussion throughout the conference. Topics included the nature of Jesuit education, its history, commitment to justice, and dialogue with culture. Speakers also addressed Jesuit-lay collaboration in higher education, the religious life of students, secularization, and the moral life of a Jesuit university. Other speakers considered Jesuit higher education from disciplinary bases while others considered its relation to administration, scholarship, and teaching. The final day was devoted to a consideration of what Jesuit higher education might, in the words of Joseph O'Hare, S.J., president of Fordham University, "look like in 2010, 2020, and 2030."

Several themes developed during the course of the weekend. A decline in the number of religious vocations to the priesthood in the post-Vatican II era and concomitant aging of the Jesuit population prompted serious discussions about the possibility of running Jesuit colleges and universities without Jesuits. There was strong consensus among those gathered that the future of Jesuit higher education in the United States depends not only upon Jesuit-lay collaboration, but in the development of lay persons deeply versant in and committed to the principles of Jesuit education as found in and informed by the Ratio Studiorum, the Constitutions of the Jesuit order, and the Spiritual Exercises of founder St. Ignatius of Loyola - which have animated Jesuit education for four and a half centuries. Throughout the conference, the "touchy" issue of "hiring for mission" surfaced with regularity, as well as training and orientation for the faculty, staff, and trustees of Jesuit colleges and universities.

Significant portions of the conference were given over to discussions of what makes Jesuit education distinctive and sets it apart from other Catholic, churchrelated, and secular institutions of higher education. Here the theme of justice emerged most clearly. Still grappling with the significance of the 32nd (1974) and 34th (1995) General Congregations of the Society of Jesus in which the Jesuits committed themselves to the service of faith and the promotion of justice, those gathered at Jesuit 21 discussed how Jesuit institutions of higher education in the United States could foster local and global justice both in terms of the formation of students and the commitments and practices of the university itself.

\section{The future of Jesuit higher education in the United States depends not only upon Jesuit-lay collaboration, but in the development of lay persons deeply versant in and committed to the principles of Jesuit education.}

Archbishop Guiseppe Pittau, S.J., secretary for the Vatican's Congregation for Catholic Education, spoke to conference participants about the importance of Jesuit and Catholic higher education in the United States, acknowledging the profound contribution made by these institutions to the American Catholic Church at large. He spoke 
as well to the issues of academic excellence, academic freedom, and institutional diversity among Catholic institutions of higher education. His comments on the difficulties of creating universal norms for diverse Catholic institutions were welcome among a group concerned, in large part, by current discussions among Vatican officials, American bishops, and university presidents about the proposed norms for implementation of John Paul II's 1990 letter on Catholic higher education, Ex corde Ecclesiae, that have raised serious legal questions for Catholic colleges and uni- versities. Though not the subject of any address, Ex corde Ecclesiae ineluctably impinged upon the conference.

Over and against those who have framed the relationship of religion and higher education as one of secularization and decline, on the whole, conference participants looked to the future of Jesuit higher education with a guarded optimism, uncertain of its future (save for its laicization), yet convinced that the spirit and dynamism of Jesuit education could survive and perhaps flourish in the 21 st century.

\section{The ERIC Clearinghouse on Higher Education}

$\mathrm{T}$ he ERIC Clearinghouse on Higher Education is a prominent center for higher education information (ERIC database, website, and publications). ERIC acquires the major published and unpublished education literature, abstracts and indexes it, and adds the literature to the ERIC database. In addition to the database, we have an extensive publications series and website that are detailed below.

Our website contains valuable resources (web links, workshops, and bibliographies) for higher education practitioners, faculty, and students. If you haven't yet been to our site, take a look: <www.eriche.org>. We are excited to announce that we have updated our website and have included some fantastic new services/sections: secure on-line credit card ordering for our ASHE-ERIC Report Series, a classroom use request form for faculty considering using a monograph from the Report Series, electronic newsletter, and Cool Higher Education Site of the Month.

We would also like to introduce you to our major, award-winning publication: The ASHE-ERIC Higher Education Report Series. The Association for the Study of Higher Education and the ERIC Clearinghouse on Higher Education publishes eight reports each year. It is the most peer-reviewed and widely distributed series on higher education in the United States. Many professionals in higher education have daily responsibilities that preclude keeping up with all the major research and scholarly literature affecting their work, their institutions, and their professional development. These 120page monographs help to fill this gap, drawing on the ERIC database to synthesize the latest research and report on activities that affect higher education institutions, personnel, and programs.

The ASHE-ERIC Higher Education Report Series is always looking for new authors to submit proposals for future monographs! Please see our website for a list of calls for proposals, author guidelines, and sample monographs proposals or contact us at 1-800-773-ERIC.

\section{ASHE Annual International Forum}

November 16-18, 1999, San Antonio, Texas

$T$ he annual ASHE International Forum brings together a community of scholars dedicated to the study of education from an international and comparative perspective. The purpose of the meeting is to advance the knowledge and practice of comparative research on higher education systems, institutions, and stakeholders across nations and over time. The ASHE International Forum aims to enhance discussion, dialogue, and learning from research and experiences in different countries, using diverse theoretical frameworks and various methodological approaches. The design of this year's Forum will provide a diversity of formats to allow both delivery of papers and stimulating discussion and encourage the expansive inclusion of ideas, especially for graduate students.

We will convene our meeting November 16th-18th, 1999, immediately prior to the ASHE general conference (see below). For more information about the ASHE Council on International Higher Education, please e-mail us at <international@higher-ed.org> and visit our website at: $<$ http://www.higher-ed.org/international>.

\section{About the ASHE Conference}

For the 24th year, the Association for the Study of Higher Education (ASHE) will meet as a community of scholars dedicated to the study of higher education. The meeting will be held in San Antonio, Texas, November 18-21. For more information and registration materials, please contact:

Association for the Study of Higher Education Department of Educational Leadership and Policy Analysis 211 Hill Hall

University of Missouri-Columbia Columbia, MO 65211

Phone: (573) 882-9645

Fax: (573) 884-2197

E-Mail: ashe@tiger.coe.missouri.edu Web: http://www.coe.missouri.edu/ ashe 